\title{
FIGURING OUT FIGURINES
}

\author{
Philip Johnston
}

\begin{abstract}
Summary
Almost one thousand Judaean pillar figurines, or JPFs, have now been found. These small terracotta female figurines are distinctive to late monarchy Judah. They have been found all over its territory, but seldom elsewhere, and come almost entirely from the eighth and seventh centuries BC. Who or what do they represent? This article first summarises recent study of figurines, to set out their known characteristics. It then looks for textual evidence of figurines. It examines inscriptional and biblical references to Asherah, the main goddess of the Iron Age Levant and now often associated with these figurines, as well as other potential biblical terms. However, while there are many terms for images and idols, none is found to apply specifically to figurines. Finally it reviews the interpretation of figurines, concluding with observations which combine archaeological and biblical data.
\end{abstract}

\section{Introduction}

What are figurines? What forms do they take? At what sites and in what archaeological contexts have they been found? What do they represent, and how were they used? What light does this shed on religious beliefs? And how does the archaeological evidence of figurines relate to the textual evidence of inscriptions and the Hebrew Bible? These are all important questions, prompted by a century of archaeological study in Palestine, which this paper will attempt to address.

To start with the figurines themselves, these are small, usually handsize figures shaped as humans, animals, birds, or inanimate objects. They were made of various materials, mostly metal or clay. They have

1 The Tyndale Fellowship Old Testament Lecture, 4 July 2002. 
been found all over the ancient world, from the Aegean to Mesopotamia, from Palaeolithic times onwards. Here we focus particularly on one area and period.

Several thousand figurines have been recovered from late monarchy Judah. These include nearly a thousand anthropoid figurines, almost exclusively female. They come from throughout Judah, particularly Jerusalem, and have been found in public buildings, private homes, storage caves, rubbish pits and tombs.

These female figurines have a specific size and shape. They were made of baked clay (terracotta), and stand about 10-21 cm high, with stereotypical bodies. They have full or heavy breasts, with hands supporting the breasts or arms folded beneath them, sometimes as a continuous band. They have a solid pillar base from the lower chest downward, without further indication of sexuality, and a flared base. They were at least partially painted.

About one-third have a hand-made head, made from the same lump of clay, with the front of the head pinched to form two depressions for the eyes and a ridge for the nose, giving them a bird-like appearance. These figurines are slightly smaller, about $10-16 \mathrm{~cm}$ high. The other two-thirds have a moulded head, made separately and joined to the body by a peg hidden in the neck. The moulded heads have a round full face, smiling mouth and large eyes. The hair is short and curled, with minor variations in style, though whether this represents natural hair or a wig is unclear. These figurines are slightly larger, $14-21 \mathrm{~cm}$ high, with heads often disproportionately large for the body.

These female pillar figurines were distinctive to late monarchy Judah. They are significantly different both from figurines in Judah in earlier and later periods, and from figurines in neighbouring territories in the same period: Transjordan, northern Israel, the coastal plain and Phoenicia. Hence they are now often called Judaean Pillar Figurines, or JPFs.

Many other figurines have been found along with the JPFs, representing birds, quadrupeds (mainly horses) and a few horseback riders. Indeed, these animal figurines are far more numerous than the JPFs, though they have often attracted less attention in archaeological reports and interpretative syntheses.

There is now a general consensus that the JPFs represent the goddess Asherah and testify to her widespread veneration throughout late monarchy Judah, despite the 'reforms' of Hezekiah and Josiah. They apparently provide important evidence for the pluralist nature of Judaean religion, and show that the biblical text incorrectly projects an exclusive Yahwistic monotheism back onto this period. Thus the dust 
cover of Z. Zevit's recent magnum opus, The Religions of Ancient Israel, ${ }^{2}$ portrays a group of figurines as evidence for the plural in his title.

\section{The Figurines}

\subsection{Scholarly Study}

'The study of Israelite figurines has as long a history as that of Israelite archaeology itself.' ${ }^{3}$ But recently the number of figurines and the extent of their study have increased dramatically. Three studies are particularly detailed: T.A. Holland (1975) catalogued all known figurines while concentrating on those of Jerusalem; 4 D. Gilbert-Peretz (1996) focused on figurines uncovered in the City of David excavations; 5 and R. Kletter (1996) provides a comprehensive synthesis of all the material available to $1995 .^{6}$ These authors provide most of the data for the following summary and interpretation.

Kletter helpfully divides the history of research into four phases. First, the period to 1912, during which a handful of JPFs were discovered. Some of these were at Gezer and Beth Shemesh, where Macalister and Mackenzie respectively saw them as expressions of magic.

Secondly, between the World Wars, when most female figurines were labelled 'Astarte' since she was then considered the main goddess of the region. Pillar figurines were found at Beth Shemesh, Tell Beit Mirsim and Tell en-Nasbeh. Meanwhile excavations outside Judah, notably at Samaria and Megiddo, revealed virtually no Judaean-style figurines. Pilz (1924) catalogued some 123 known figurines and made astute observations: figurines were not cult statues but copies related to

2 Z. Zevit, The Religions of Ancient Israel (London: Continuum, 2001).

3 K. van der Toorn, 'Israelite Figurines: A View from the Texts', in B.M. Gittlen, ed., Sacred Time, Sacred Place (Winona Lake: Eisenbrauns, 2002), 45.

4 'A Typological and Archaeological Study of Human and Animal Representations in the Plastic Art of Palestine during the Iron Age', Oxford D.Phil. Dissertation; summarized in 'A Study of Palestinian Iron Age Baked Clay Figurines', Levant 9 (1977) 121-55.

5 'Ceramic Figurines', Qedem 35 (1996) 29-41; delayed in publication, with bibliography up to 1989 .

6 The Judean Pillar-Figurines and the Archaeology of Asherah (Oxford: Tempus Reparatum, 1996). Summary in a 1996 paper: 'Between Archaeology and Theology: The Pillar Figurines from Judah and the Asherah', in A. Mazar, ed., Studies in the Archaeology of the Iron Age in Israel and Jordan (JSOTSup 331, Sheffield: SAP, 2001), 179-216. 
'popular religion'; and if they represented a goddess, then Yahwism had not suppressed her cult. Albright called her the nurturing goddess (dea nutrix). Pritchard (1943) classified 249 female figurines, 52 of which he termed pillar figurines. For him they were a direct continuation of plaque figurines, and represented womankind or the mother goddess or a domestic nurturing cult. ${ }^{7}$

Thirdly, 1945-1975, when there were many important new excavations, notably at Lachish, Jerusalem, Gibeon and Ramat Rahel. Dozens of figurines were found at many sites, and hundreds by Kenyon in Jerusalem. There were also new excavations outside Judah, notably at Hazor, Taanach, Samaria and Ashdod. As before, figurines found at these non-Judaean sites exhibit a marked contrast with the JPFs. The latter were identified variously as: an unnamed mother goddess or fertility goddess; a specific deity, usually Asherah now rather than Astarte; lucky charms; and even toys (see further below). However, various caveats were also noted, e.g. fertility might not be the primary element, since the lower body was unrepresented; and popular religion might not be an appropriate term, since some were found in the palace complex at Ramat Rahel.

Holland (1975) classified some 2711 artifacts from over 100 sites, ${ }^{8}$ including 958 figurines (of which 573 are pillar figurines). Animal forms outnumbered human by about three to two $(1,555$ to 1,100$)$. Of the human figurines, Holland concluded the solid-bodied (his Type A) were mainly Judaean and hollow-bodied (his Type B) mainly northern, under non-Israelite influence. He provided a detailed catalogue and typology of known figurines, but offered little synthesis.

Fourthly, 1975-1995, labelled the 'Asherah' phase because of renewed interest in the goddess. Engle (1979) reclassified the moulded figurine heads, what he called 'the best specimens of the most characteristic group'. ${ }^{9}$ Gilbert-Peretz (1966) followed Holland's typology. As noted, Kletter (1996) has produced the largest study so far, comprising 80 A4-sized double-columned pages of text, plus 185 pages of figures, tables and catalogues. He offers a comprehensive

7 Kletter, Judean, 10-12. Pritchard's classification is presented in more detail by Zevit, Religions, 268.

888 sites west of the Jordan, roughly from Hazor to Beersheba, and 20 in Transjordan; 'Study', 126-29. A few artifacts were of unknown provenance, and about 1000 were previously unpublished.

9 As cited in J.M. Hadley, The Cult of Asherah in Ancient Israel and Judah (Cambridge: CUP, 2000), 197. For Engle, JPFs were supplementary evidence concerning Asherah (so Kletter, Judean, 17, 28). 
study of 854 JPFs using a simple typology. 10 Until very recently, this study was largely unknown to biblical scholars, ${ }^{11}$ and has received only one significant review, in BASOR.12

The number of known figurines is continually rising, as shown by the numbers involved in successive studies (with JPFs in parentheses): Pilz: 123 (7); Pritchard: 249 (14), Holland: 958 (359); Kletter 1852 (854). ${ }^{13}$ Meanwhile excavations continue to produce more examples. ${ }^{14}$

While most of the interest has focused on human figurines, it is worth noting the large number of animal figurines discovered. They constitute a slight majority in Holland's analysis, and the large majority in the more recent City of David excavations. Quite possibly they were the significant majority generally, but were under-recorded in early excavations. Many are so broken as to be scarcely recognizable, i.e. with head, neck and all limbs missing.

There is also a dearth of male figurines. 15 There are a few male horseback riders, mostly pillar based, and some horses with a flat back to accommodate such a base. But they are much less frequent than female pillar figurines. And there are hardly any other male figurines.

\subsection{Manufacture and Breakage}

JPFs were made from poor quality clay fired at low temperatures (c. $600-700^{\circ}$ Celsius), which accounts for their fragility. Sample analysis has now shown that the moulded heads were foreign imports but were made from local clay. ${ }^{16}$ The detailed head moulds, ${ }^{17}$ stereotypical

10 His Type A, pinched heads, 198; Type B, moulded heads, 208; Type C, body fragments with unknown head type, 448.

11 An exception is P.D. Miller, The Religion of Ancient Israel (Louisville: WJKP, 2000), 233 n. 167.

12 R. Tappy in BASOR 310 (May 1998) 85-89; also brief notice in $R B 150$ (1998) 464. It is not reviewed in the 1997-2001 editions of: $B A / N E A, B O, C B Q, I E J, J B L$, $P E Q$, SOTS Book List, VT. Tappy notes many loose ends and minor inconsistencies, resulting from the complex data and inadequate editing. But he makes little allowance for a combative thesis style or its being written in English, and incorrectly criticises Kletter for ignoring Albertz and Berlinerblau.

13 So Kletter, Judean, 83, Fig. 2.

14 E. Stern, 'Religion in Palestine in the Assyrian and Persian Periods', in B. Becking, M.C.A. Korpel, eds, The Crisis of Israelite Religion (OTS 42, Leiden: Brill, 1999), 251, notes many more discovered since Kletter's study.

15 Kletter lists only 5 male figurines from Judah, and no animals, whereas GilbertPeretz notes more males.

16 Kletter notes different clays in Jerusalem, the Negev and the Shephelah; Judean, 49.

17 Kletter, Judean, 48, attributes minor differences to regional workshops, e.g. 'hammer' heads in the Negev, 'turban' heads in the northern Judaean mountains. 
designs ${ }^{18}$ and firing requirements point to bulk manufacture in local potteries rather than individual homes.

JPFs were probably all painted, first with a white slip or white-wash, then with a banded colour (red, yellow, brown, black, sometimes bichrome), probably representing necklaces and bracelets. ${ }^{19}$ There is no surviving painted representation of clothing.

Little attention was paid to the back of figurines, with the clay of body and head left unfinished and unpainted. They were obviously intended to be viewed from the front, probably in a fixed position. Conversely they were not intended to be handled or carried about, and certainly not to be played with.

Some scholars surmise that figurines were deliberately damaged in ritual acts or by iconoclastic reformers. ${ }^{20}$ This is because the vast majority have been found broken, 21 not just at weaker points like the nose, neck or arms, but sometimes in the structurally strong body. Further, there is evidence from elsewhere in the ancient Near East of deliberate breakage or mutilation of figurines. ${ }^{22}$

However, Kletter cautions against assuming deliberate breakage, for several good reasons. (a) There is no evidence of deliberate breakage of the body or mutilation of the face. (b) An experiment in which modern figurines, manufactured like the JPFs, were dropped from a high shelf onto suitable floors, gives breakages in roughly similar places. (c) The breakage level of JPFs is similar to breakage levels of other excavated artifacts. (d) 'The JPFs appear as good figures (the smile, the full face, the breasts which may be portrayed as being offered). If they also functioned as good figures, it is hard to see why they should be mutilated in ritual acts.' 23

\subsection{Date}

Some scholars have suggested that JPFs began to appear in the tenth century. However, Kletter argues that there is minimal secure evidence

\footnotetext{
18 Kletter, Judean, 73: 'overwhelming uniformity—indeed even stereotyping — of shape'.

19 Gilbert-Peretz, 'Ceramic', 37: ' $85 \%$... still retained their white slip.' Kletter, Judean, 50, records whitewash on 199 and paint on 99.

20 E.g. G. Barkay, 'The Iron-Age II-III', in A. Ben-Tor, ed., Archaeology of Ancient Israel (New Haven: Yale University Press, 1992), 362; tentatively Holland, 'Study', 137.

21 Only 5\% of Kletter's sample were complete, mostly those found in graves.

22 E.g. Egyptian execration figurines, broken to activate curses; a fourth millennium Cypriot stone figurine (Kletter, Judean, 54).

23 Kletter, Judean, 56. Similarly van der Toorn, 'Israelite', 53: 'most of them show no traces of maltreatment'.
} 
for both tenth and ninth centuries, concluding: "the amount of "early" dated JPFs is so meager, that their importance is negligible. The JPFs are recognised as a common, substantial phenomenon starting with the 8th century.' Gilbert-Peretz argues similarly: 'In sum, Type A [i.e. JPFs] appears in the 8th century BC ...'24

In fact, dating is often very difficult. Of Kletter's main group of 578,25 only 251 have any dating evidence. 'All the rest of the JPFs lack clear stratigraphy, having been found on the surface, in earth debris, on slopes outside the settlements, and in varied secondary contexts (such as late building fills and pits). ${ }^{26}$ Further, it is often impossible to distinguish between the eighth and seventh centuries, for two reasons. (a) In early excavations this differentiation was not possible. (b) Many Judaean hill sites were not destroyed in Sennacherib's 701 campaign, and display continuity between eighth and seventh centuries. Most recovered artifacts would come from the latest occupation phase, i.e. the decades before 586, but this assumption cannot be translated into precise figures. From the limited evidence available, Kletter notes that moulded heads were more common in the eighth century, while handmade heads were equally common in the seventh. But the evidence is too sparse to make conclusions about their relative popularity.

As often noted, there is an archaeological vacuum for the Babylonian period in Palestine, while the subsequent Persian period is poorly attested. Nevertheless, Stern concludes forcefully:

all the figurines from [the Persian period] on were found only in areas outside the region settled by the returning Judean exiles ... in the area of the country occupied by Jews, not a single cultic figurine has been found! ...Apparently, pagan cults ceased to exist among the Judeans who purified their worship and Jewish monotheism was at last consolidated. 27

It is hard to escape this conclusion.

\subsection{Geographical Distribution}

There is an obvious danger of circular argument in using a political description to label artifacts and then using those artifacts to determine political boundaries. But Kletter notes sufficient evidence from a variety of sources for defining a 'heartland of Judah', comprising 'the

24 Kletter, Judean, 40; Gilbert-Peretz, 'Ceramic', 38.

25 Kletter initially worked on $578 \mathrm{JPFs}$. The remaining 276 , now mostly published by Gilbert-Peretz, only became available later, and 'do not change radically any of the conclusions'; Judean, 218.

26 Kletter, Judean, 40.

27 Stern, 'Religion', 253-55. Similarly Kletter, Judean, 40, 79. 
Judean mountains, Benjamin, the Judean desert and the Biblical Negev'. ${ }^{28}$ He then concludes:

If we adopt the heartland of Judah concept as base for our discussion, then 822 JPFs (ca. 96\%) were found within this area. This number is so high, that there is only one possible conclusion: the JPFs are Judean figurines, found in the kingdom of Judah. This conclusion is not merely possible, it is necessary. The distribution picture is so clear, that even if we misjudged a few sites in regard to the definition of the heartland of Judah, it matters little. Outside Judah, almost no JPFs were found, i.e., in the kingdoms of Israel, Phoenicia, Philistia and Transjordan ... Local figurine assemblages appear in all these areas, and this also strengthens the conclusion above. ${ }^{29}$

The rare exceptions are 4 from the coastal plain and 9 from the north. ${ }^{30}$ Gilbert-Peretz concurs: 'with very few exceptions, these types are not found outside Judah.' 31

The number of JPFs per site varies enormously. Jerusalem has 405, almost half the total, reflecting size and status as well as extensive excavation. Tell en-Nasbeh is next with 143. Since it was no larger than other regional centres, this probably reflects extensive excavation and good publication. Then there are several sites with 50-20 JPFs: Tel Beer Sheba (43), Tell Beit Mirsim (37), Beth Shemesh (30), Lachish (29), Gibeon (27), and Arad (23). Two other sites near Jerusalem have 20-10 JPFs: Ramot (13) and Ramat Rahel (11); the rest remain in single figures. Of course, this is simply an archaeological snapshot from 1995, with all its limitations. Nonetheless, it confirms other indications of Jerusalem as the capital and outlying towns as regional centres.

Further, figurines come from 29 different sites within Judah, or 35 sites including the immediately neighbouring towns. This shows a wide distribution pattern within Judah itself. Again, Gilbert-Peretz agrees: 'The present study has shown that not only do parallels for the individual types of City of David figurines occur at other Judahite sites, but that the assemblages are extremely similar.' 32

\subsection{Archaeological Context}

JPFs have been recovered from a wide variety of contexts, notably homes, public buildings, disposal places and graves. However, many

28 Kletter, Judean, 45; also idem, 'Pots and Polities: Material Remains of Late Iron Age Judah in Relation to its Political Borders', BASOR 314 (1999) 19-54.

29 Kletter, Judean, 45, emphasis original.

30 Kletter first notes 7 northern JPFs, Judean, 56, 95 (Fig. 15); but later adds 2 from Tell el-Far'ah, Judean, 96 (Fig. 16).

31 Gilbert-Peretz, 'Ceramic', 32.

32 Gilbert-Peretz, 'Ceramic', 37. 
contexts are uncertain, particularly those from early excavations, so the comparative evidence is limited.

First, there are some 20 complete JPFs of known context. 3312 come from graves, surviving intact in their undisturbed location. Regarding these, Kletter notes: (a) no JPF has been linked with a specific skeleton, male or female; (b) burials far outnumber JPFs, so most lacked their own JPF; (c) most of the hundreds of known Iron Age II Judaean graves had no JPF. The other 8 complete JPFs were found in various locations: house (3), water cistern (2), silo pit (2) and public building (1).

Secondly, some 255 incomplete and fragmentary JPFs have a discernible context. Of these, the largest group (84) were found in houses, the next largest (59) in cisterns or dry storage pits. Others were found in streets or open areas (17), gates or storehouses (9), outside walls, in fills or in tombs. Often these are small fragments, probably discarded after breakage.

Thirdly, there is virtually no evidence that JPFs were 'used' together. Groups of fragments have occasionally been found, but generally in disposal contexts, with other pottery fragments. A very few houses contain fragments of 2-4 JPFs, but whether these ever formed a group is unknown.

By far the largest multiple context is Jerusalem Cave 1, where hundreds of JPFs and other figurines were discovered. Kenyon labelled it a favissa, and many scholars accept that it was some form of cultic storage or disposal cave. A possible incense stand would support this. However, Kletter strongly disputes this, and sees it as a storage assemblage. Whatever the cave's exact nature, the JPFs were apparently deposited rather than used there, so Cave 1 does not constitute evidence for JPF groups.

Finally, there is little evidence on the relationship of JPFs to other figurines. As noted, there are very few male figurines, and no real evidence for male-female pairs. Horse and rider figurines and animals have been found with JPFs, but mostly in disposal contexts. Only the bird figurines perhaps appear occasionally with JPFs in contexts of use, but even this is unclear.

The picture, then, as far as available evidence shows, is that some houses had JPFs, singly rather than with other JPFs or other figurines. A few public locations like storehouses also had single JPFs, though they are extremely rare in cultic buildings. When a JPF broke, it was

33 Figures and analysis here follow Kletter, Judean, 57-67. 
discarded, thrown into the street or a water cistern or outside the wall, and presumably replaced.

\section{The Texts}

\subsection{Asherah in the Levant}

As noted above, the JPFs are now commonly identified with Asherah. 'Asherah literature' has blossomed recently, with at least a dozen theses in the last quarter century, many published as monographs, ${ }^{34}$ and other works far too numerous to list. Non-biblical textual data includes the now well-known texts from Ugarit and the inscriptions at Khirbet el-Qom and Kuntillet 'Ajrud, plus various other material. This ground has been well covered already, not least in a Tyndale Fellowship Lecture a decade ago by Hess and in the recently published thesis of Hadley, 35 and the major conclusions will be summarised below.

The goddess 'trt' 'šrt was apparently unknown at Ebla in the late third millennium. For Hess, 'This absence of evidence suggests that the deity was not present in Syria before the appearance of the Amorites.' 36 By contrast, 'šrt was a deity in LBA Amurru (Tyre), as testified by the Amarna correspondence. Here a ruler called abdi-a-ši-ir-te is mentioned some 95 times. Hess argues that the deity's name was aširta, with a final vowel that is not simply a case ending. ${ }^{37}$ Another possible reference to the goddess occurs in a LBA Akkadian tablet from Taanach: ${ }^{d} a-s ̌ s-r a t$. But the unusual spelling (uniquely with rat), uncertain context and disputed reading all caution against using this as evidence. 38

There is much evidence from Ugarit for the goddess 'trt (traditionally 'Athirat', the equivalent of Hebrew Asherah), also called

\footnotetext{
34 Notably (with italics for unpublished theses): A.L. Perleman (1978), J.R. Engle (1979), U. Winter (1983), W.A. Meier (1986), S. Schroer (1987), S.M. Olyan (1988), R.J. Pettey (1990), S.A. Wiggins (1993), R. Huntziker-Rodewald (1993), C. Frevel (1995), T. Binger (1997), J.M. Hadley (2000). Earlier important studies include W.L. Reed (1949) and R. Patai (1967).

35 R.S. Hess, 'Yahweh and His Asherah?' in A.D. Clarke, B.W. Winter, eds, One God, One Lord (Cambridge: Tyndale House, 1991), 5-33; Hadley, Cult.

36 R.S. Hess, 'Asherah or Asherata?', Orientalia 65 (1996) 209. For the Amorites, Asherah was a consort of Martu; cf. M.P. Streck, Das amurritische Onomastikon der altbabylonischen Zeit (AOAT 271/1, Münster: Ugarit-Verlag), 69.

37 Hess, 'Asherah', 214, with detailed examination of the variants; cf. his 'Yahweh', 13; also Zevit, Religions, 404.

38 So Hess, 'Asherah', 215.
} 
the 'Great Goddess of the Sea'. Wyatt summarises:39 'In the "Baal cycle" of myths, she is a great goddess, mother of the minor gods of the pantheon ... who intercedes for Baal and Anat before El, and who supplies a son to reign following the descent of Baal into the netherworld.' She also appears in the Keret epic as a Phoenician deity who will nourish Keret's heir, and in various other texts. 40

At Tel Miqne (Ekron) several seventh-century storejars have dedicatory inscriptions: two have 1 '̌stt, one with $q d \check{s}$ on the opposite side giving 'Holy to ' $\breve{s r t} ;$; three others have $q d \check{s}$, in one case followed by $I$ and an uncertain word; the sixth has $1 \mathrm{mqm}$. The language of these inscriptions in uncertain: it "could be early Hebrew, Phoenician, or even Philistine'. ${ }^{2}$ Many read 'šrt as a reference to the deity Asherah, spelt with a final $t .43$ Differently, and surprisingly in light of her thesis, Hadley suggests that this 'šrt means 'shrine'. ${ }^{44}$ But the excavator Gitin argues against this, since Imqm (the sixth inscription) means 'for the shrine'. ${ }^{45}$ Thus 'šrt probably indicates Asherah.

The important eighth-century Hebrew inscriptions are: 46

Kuntillet 'Ajrud, Pithos A

brkt 'tkm lyhwh ̌̌mrn wl'šrth

I bless you by Yahweh of Samaria and by 'A'

Kuntillet 'Ajrud, Pithos B

brktk lyhwh tmn wl'šrth ${ }^{47}$

I bless you by Yahweh of Teiman and by 'A'

Khirbet el-Qom

brk 'ryhw lyhwh wmstyh l'šrth hwšs' Ih

39 N. Wyatt, 'Asherah', $D D D^{2}, 99$, omitting references.

40 Cf. Hadley, Cult, ch 2. Also in the name abdi-a- $\breve{S A R}$ - $t$ (three times); cf. Hess, 'Asherah', 210.

41 Most scholars interpret the words together, though they could be unrelated.

42 S. Gitin, 'Seventh Century B.C.E. Cultic Elements at Ekron', in J. Aviram, A. Biran, eds, Biblical Archaeology Today, 1990 (Jerusalem: IES, 1993), 252.

43 E.g. Hess, 'Asherah', 217. Gitin, 'Seventh', 257 n. 37, notes that feminine endings in -at are common in Phoenician, and occur in Hebrew names Zarephath, Gibeath (cf. GK $§ 80 f)$.

44 As in Phoenician; so Hadley, Cult, 180-84, following Lipiński here but not on the other inscriptions.

45 Gitin, 'Seventh', 252; similarly Zevit, Religions, 402.

46 The drawings on the Kuntillet 'Ajrud pithoi are also much discussed, and their relationship to the inscriptions remains disputed.

47 J. Renz, Die Althebräischen Inschriften (Darmstadt: Wissenschaftliche Buchgesellschaft, 1995), 62, reads $1 y h w[h]$. 
Blessed be Uriyahu by Yahweh, and from his enemies by 'A' he has saved $\operatorname{him}^{48}$

or: Blessed be Uriyahu by Yahweh, and his Egyptian by 'A'. He has delivered him ...49

A key question is whether 'srth (left as 'A' above) should be translated as 'his shrine', 'his asherah' (cultic symbol), 'his Asherah' or 'Asherata':

(a) 'his shrine'. ${ }^{50}$ This meaning of 'šrt is attested in Phoenician and other ancient Semitic languages. However, this usage is not clearly attested in Hebrew (despite some proposals), and the interpretation is largely rejected.

(b) 'his asherah'.51 This implies that Yahweh was represented by a cultic object, probably some form of pole. To what extent Yahweh's asherah (pole) also represented Asherah (deity), perhaps his consort, is much debated. As often noted, deity and cultic symbol were not clearly distinguished in the ancient Near East. ${ }^{52}$ But this does not explain how Asherah's symbol became associated with Yahweh.

(c) 'his Asherah'. This involves a pronominal suffix attached to a name. However, most scholars note that this construction is unattested elsewhere in Hebrew and conclude that this reading is impossible. 53

(d) 'Asherata'. Here the last two letters are an integral part of the goddess's name, not the pronominal suffix 'his' ${ }^{54}$ The $t$ is radical, and the final $h$ a mater lectionis for a vowel. Hess notes that all other extrabiblical West-Semitic attestations of the name end in $t$ or in $t+$ vowel, whereas only the biblical text spells the name with final $h$. Zevit concurs, concluding: 'This explanation posits a new form of the name, but one which is contextually sound, attested at more than one site, and philologically likely.' 55

48 Majority interpretation; cf. Hadley, Cult, ch. 4; Renz, Althebräischen, 209f.

49 Hess, 'Yahweh', 24, following Shea.

50 Lipiński, Lemaire, Perleman; so Hadley, Cult, 5, 105.

51 Most scholars, e.g. J.A. Emerton, "YYahweh and his Asherah": The Goddess or Her Symbol?', VT 49 (1999) 315-37; Hadley, Cult.

52 Cf. Hadley, Cult, 7, citing examples from Mesopotamia and Egypt.

53 Zevit, Religions, 402f. notes that suggested examples of divine name + suffix in Ugaritic are most uncertain ('only one possible example'), and in Akkadian and Eblaite are rare.

54 Hess, 'Yahweh', 13-15, 19f.: 'the spelling Asherah / asherah in the Hebrew Bible occurs nowhere in extra-Biblical Hebrew inscriptions of the Monarchy or earlier' (13); following Angerstorfer.

55 Zevit, Religions, 403. 
In sum, those who translate 'šth as 'his asherah' prioritise the spelling of biblical Hebrew, ${ }^{56}$ while those who argue for 'Asherata' prioritise the extra-biblical evidence. Whatever the precise meaning of these inscriptions, Asherah was clearly an important deity in the Levant in the Late Bronze Age and Iron Age. But whether the term was also used for a cultic symbol associated with Yahweh remains unclear.

\subsection{Asherah in the Hebrew Bible}

The term 'ăšerāh occurs 40 times in the Hebrew Bible, particularly in Judges $(5 \times)$, Kings $(16 \times)$ and Chronicles $(11 \times)$, with a few uses in the Pentateuch $(4 \times)$ and the prophets $(4 \times) .57$ It occurs almost equally in feminine $(21 \times$, usually singular) and masculine $(19 \times$, always plural), but more often with definite article or suffix $(31 \times)$ than without $(9 \times)$. The term occurs in the feminine in Judges; in both genders in Kings (usually fem.) and Chronicles (usually masc.); and mostly in the masculine elsewhere. Some suggest that the feminine singular is an early form for both the goddess and her image; the masculine plural is a later form for her images, and the only form known in the post-exilic era when the association with the goddess was forgotten or obscured; 58 and the feminine plural $(3 \times)$ is largely a corruption. 59 This is possible, but the evidence is not clear-cut. 60

Most agree that 'ăšer $\mathrm{ra} h$ indicates the goddess herself in several texts: Judges 3:7 (the Baals and the ăšserôt); 1 Kings 15:13 // 2 Chronicles 15:16 (Maacah's abominable image for Asherah); 1 Kings 18:19 (450 prophets of Baal and 400 prophets of Asherah); 2 Kings 21:7 (Manasseh's carved image of Asherah); 2 Kings 23:4 (vessels for Asherah); and 2 Kings 23:7 (weaving for Asherah). In six of these, ăšerāah has the definite article. ${ }^{61}$ While there are possible grammatical

56 E.g. Emerton, 'Yahweh', 323 n. 4, views the final $t$ in the Ekron inscriptions as an old feminine form, and indecisive for the eighth-century Hebrew inscriptions.

57 Subdivided differently, 24 of the 40 occurrences are in Deuteronomistic material.

58 Hadley suggests that Asherah as goddess was being forgotten in the Deuteronomists' time. But 2 Ki. 23:4 indicates the opposite for J. Day, Review of Hadley, ExpTim 112 (2001) 139.

59 So Wyatt, 'Asherah', 102f., emending two (Judg. 3:7; 2 Ch. 33:3) and ignoring the third (2 Ch. 19:3).

60 Chronicles normally uses masculine plural, but has 3 feminine forms: 2 Ch. 15:16 (sg.; Maacah's Asherah) // 1 Ki. 15:3 (sg.); 2 Ch. 33:3 (pl.; Hezekiah's reform) // 2 Ki. 18:4 (sg.); 2 Ch. 19:3 (pl.; Jehoshaphat's reform, $\neq 2$ Ki. 22:43).

61 All but 2 Ch. 15:16. 
caveats, ${ }^{62}$ this illustrates that the term was not treated entirely as a personal name by the final editors, and perhaps also at earlier stages.

These texts suggest veneration of Asherah in the judges period, tenth-century Judah (Maacah), ninth-century Israel (Mt Carmel confrontation) and seventh-century Judah (Manasseh). However, the authenticity of the two texts associating Asherah with Baal has been questioned. In Judges 3:7 the plural is unusual and there is some late textual evidence for 'Ashtaroth';63 in 1 Kings 18:19 the prophets of Asherah differ from the prophets of Baal in number and in grammar (no object marker ' $\bar{e} t$ ). For some, this points to later editorial activity to discredit Asherah by association with Baal rather than Yahweh.

Conversely, the majority of references to 'ăšerāh or 'ăšêrîm indicate a cultic object. As Burns summarises: 'The figure was made of wood, planted/driven into the ground or erected, often beside an altar. Thus it could be cut down, broken into pieces, burnt, and pounded into dust.' It is also widely agreed that as a cultic object 'ăšerāh was most likely an artificial and stylised sacred tree'.64 Veneration of this wooden cultic object representing Asherah was a pervasive sin, according to Judges, Kings and Chronicles. But the language used of 'ăšêrîm precludes it as a term for JPFs.

Given the forthright condemnation of non-Yahwistic worship in prophetic texts, they contain surprisingly few references to ăšêrîm. For Wyatt, 'the paucity of prophetic references is striking'; indeed, 'the few prophetic allusions are all best explained as later additions to the text'.65 There are four such references, one in Jeremiah (17:2) and three in ostensibly eighth-century material, seen as late by most scholars for form-critical and socio-religious reasons, 66 but accepted as authentic by some others: Micah 5:14,67 Isaiah 17:8,68 and Isaiah

62 Judg. 3:7 refers generically to Baals and Asherahs; in 1 Ki. 18:19 and 2 Ki. 21:7 ăšerāh follows a construct, with the article defining the whole expression; in the other three the article is simply a matter of pointing (under a I); cf. Hadley, Cult, 62. Further, $1 \mathrm{Ki} .15: 13$ is indefinite in many MSS (cf. Even-Shoshan), like its parallel 2 Ch. 15:16. 63 So 2 MSS, Syriac, Vulgate; followed by Wyatt, 'Asherah', 102; discussion in Hadley, Cult, 63f.

64 J.B. Burns, 'Female Pillar Figurines of the Iron Age: A Study in Text and Artifact', AUSS 36 (1998), 24, omitting references. Cf. fuller list of related verbs in Hadley, Cult, $54 \mathrm{f}$.

65 Wyatt, 'Asherah', 103. Similarly Hadley, Cult, 75.

66 Socio-religious grounds for judging material as secondary are uncertain, since they often involve assessing textual value in the light of scholarly reconstruction.

67 For D.R. Hillers, Micah (Philadelphia, Fortress), 74, 'the passage seems congruent with the times of Hezekiah'. 
27:9.69 But whether this condemnation is an eighth-century or later perspective, the notable paucity of such texts indicates that the prophetic movement did not especially target Asherah worship, still less single it out for condemnation. For them it was simply one minor element of pervasive idolatry.

In summary, the references to venerating 'ăšērāh / 'ăšêrîm fit the wider biblical picture of gross corruption in the judges period and repeated but often very partial reforms during the monarchy. However, it is noteworthy that nothing in the biblical text specifically links Asherah or the ăšêrîm to widespread small images like JPFs.

\subsection{Other Image Terms in the Hebrew Bible}

Are the Judaean pillar figurines ever mentioned by other terms? In a good survey of the evidence, Burns begins: 'However polemic its intent, and not without a certain irony, the Hebrew Bible testifies eloquently to the manufacture and use of cultic images of wood, stone and precious metal in ancient Israel ... Not including the references to 'ăšèrāh and 'ăšerîm, there are some 200 occurrences of some 12 terms that signify cultic images.' We review these terms briefly, in order of frequency.

(1) pesel (54×),70 usually translated 'carved image', is the most frequent, with clusters in Pentateuchal prohibition $(10 \times)$, the Micah story in Judges 17-18 (8×), prophetic mockery in Isaiah 40-55 (10×), and a scattering through other books. In condemnation, it is often paired with masșēbôt ('pillars') and 'ăšêrîm (Dt. 7:5, 12:3; Mi. 5:13). In most cases its size, shape and identity is unspecified. Perhaps many were small, especially in households. However, Manasseh placed a pesel of (the) Asherah in the temple (2 Ki. 21:7), so presumably this one was significant in size or value.

A peselwas usually wooden, as shown in the expression 'their wooden idols' ('ês pislām, Is. 45:20) and the verbs 'burn' and 'hew down' (Dt. 7:5, 12:3). It could also be metallic: it was 'cast' (Is. 40:19, 44:10) or 'beaten into powder' ( 2 Ch. 34:7); it was linked with 'molten image' (see below), silver (Is. 30:22) and metal-smiths (Je. 10:14). Micah's pesel may have been solid silver (worth 1,100 pieces, Judg.

68 M.A. Sweeney, Isaiah 1-39 with an Introduction to Prophetic Literature (FOTL 16, Grand Rapids: Eerdmans, 1996), 261, sees structural unity in 17:1-18:7, and its social setting in the decade after the Syro-Ephraimite war.

$69 \mathrm{~J}$. Vermeylen sees reuse of earlier material here, according to B.S. Childs, Isaiah (OTL, London: SCM, 2001), 194.

70 The plural form pěsîlîm $(23 \times)$ unusually has a full-long $i$ (sometimes defectively, e.g. 2 Ch. 34:7). BDB posits a root pāsîl (similarly J.M. Hadley, NIDOTTE 3:644). 
17:3), but precious metal was normally a plating. This association with metal makes pesel an unlikely term for the JPFs.

(2) gillûlîm (48×) occurs predominantly in Ezekiel's relentless condemnation $(39 \times)$. Many see it as a late pre-exilic term, perhaps even coined by Ezekiel himself from $g-l-l$ 'to roll', indicating rounded images, or from gālāl 'dung', implying 'dung idols' or (echoing Ezekiel's invective) 'shitgods'. ${ }^{71}$ For Preuss it is 'an artificially created and cacophonous term of abuse which calls to mind and is analogous to 'élîlîm, and especially to šiqqûsîm, which originated with Hosea'. 72

Deuteronomy 29:17 talks of 'filthy idols of wood and stone, of silver and gold', which suggests a generic term. Leviticus 26:30, the other Pentateuchal reference, associates them with the high places, to be destroyed along with the latter (cf. Ezk. 6:4-6). Elsewhere the outraged Ezekiel associates gillûlîm with open-air cultic places, the defiled temple, foreign nations, Israel's ancestors, child sacrifice and priestly ministry. ${ }^{73}$ Kings associates gillûlîm with Israel's predecessors the Amorites and with her own apostate kings. Whenever coined, gillûlîm was a general term for all types of images, whatever their material, size or location.

(3) šiqqûs (28×), 'abominable things', occasionally indicates idols, specifically the foreign gods accommodated by Solomon and removed by Josiah (1 Ki. 11:5,7; 2 Ki. 23:13), and of the ultimate defiling statue, 'the abomination that makes desolate' in Daniel (11:31, 12:11). Elsewhere it is plural and more general. The specific uses imply large images in central shrines, though other texts could include smaller household objects.

(4) massēkāh (26×, including $5 \times$ in Judg. 17-18) refers primarily to a molten image. It occasionally occurs with peselin parallel or hendiadys (pesel ûmassēkāh), ${ }^{74}$ suggesting an image carved in wood and plated in metal. 75 This makes it an inappropriate term for figurines.

(5) 'élill $(20 \times)^{76}$ may be a deliberately disparaging corruption of 'êlohîm to give 'godling'. It occurs particularly in Isaiah 1-39 (10×) to ridicule such images. At one point (2:20) the prophet describes them as 'idols of silver and idols of gold'. This makes it an unlikely term for figurines.

71 So D. Bodi, 'Les gillûlîm chez Ezéchiel et dans l'Ancien Testament ...', RB 100 (1993) 481, 510.

72 H.D. Preuss, gillûlîm, TDOT 3, 2.

73 Ezk. 6:13; 8:10; 20:7f., 23:30, 30:13; 20:24; 23:37; and 44:12.

74 Parallel: Hab. 2:8; hendiadys: Dt. 27:15, Judg. 17:3,4, 18:14, Na. 1:14.

75 So C. Dohmen, massēkâ, TDOT 8, 432.

76 Not $15 \times$, pace Burns, 'Female', 28. 
(6) ‘̆sabbîm $\left(17 \times\right.$, normally plural) ${ }^{77}$ usually refers to metal images of foreign deities, of Philistines, Canaanites or the nations generally. However, occasionally it indicates idols of Israel or Judah.78 Several texts imply that these are normally major cultic images, made of metal and kept in temples. 79

(7) selem $(17 \times)$ indicates a statue or image. It is a general term, occasionally associated with metal, as in 'cast images' (Nu. 33:52) and the golden models of tumours and mice (1 Sa. 6:5-6). It is used of images of Baal destroyed at Joash's enthronement (2 Ki. 11:18) and of the enigmatic 'Kaiwan your image(s)' (lit., Am. 5:26). 80

(8) tèrāpîm $(15 \times$, always plural) occurs in three narratives: Laban and Rachel (Gn. 31), Micah (Judg. 17-18) and David and Michal (1 Sa. 19). Some were small enough to fit into saddle bags, others the size of a man. ${ }^{81}$ Elsewhere there are only a few scattered references, alongside other cultic paraphernalia (Judg. 17:5; Ho. 3:4), ${ }^{82}$ and with 'iniquity' (1 Sa. 15:23) and 'mediums, wizards, ... idols, and all the abominations ...' (2 Ki. 23:24) in two programmatic texts. Scholars increasingly identify teraphim as images of deceased ancestors venerated in family cults, though the extent of such cults is far from certain. ${ }^{83}$ The very limited use of terāâtm in accounts of the late monarchy period makes it an unlikely term for figurines.

(9) Several very occasional terms complete the picture. (a) semel $(5 \times)$, like selem, indicates a representational image. ${ }^{84}$ Manasseh's pesel hă ăšerrāh in 2 Kings (21:7) becomes his pesel hassemel 'the carved image of the idol' in 2 Chronicles (33:7), through ignorance or possibly deliberate avoidance of the term by the Chronicler. Ezekiel $(8: 2,5)$ sees an 'image of jealousy' in the Jerusalem temple, unidentified but nonetheless abominable. (b) mipleset (4×), from a root meaning 'shudder, occurs only in parallel accounts of the horrifying

\footnotetext{
77 Singular in Is. 48:5 ('ōseb), Je. 22:28 ('eseb).

78 Israel: Ho: 4:17, 8:4, 13:2, (14:8); Judah: Is. 10:11 (Zc. 13:2).

79 Respectively: Ps. 115:4; 1 Sa. 31:9 // 1 Ch. 10:9.

80 Cf. NRSV: 'Kaiwan your star-god'; similarly S.M. Paul, Amos (Hermeneia, Minneapolis: Fortress, 1991), 188, 196.

81 The singular suffix ('its head', 1 Sa. 19:13) suggests a single image in David's bed, rather than several together.

82 There is no indication of the number of teraphim in Ho. 3:4, pace Burns, 'Female', 28.

83 See P.S. Johnston, Shades of Sheol (Leicester: Apollos, 2002) ch. 8 for further discussion.

84 It may have a Phoenician origin; cf. Hadley, Cult, 68, and references.
} 
image for Asherah made by Maacah and removed by Asa. ${ }^{85}$ (c) Finally, 'êmāh, normally 'fear', seems once in the plural 'êmîm to mean 'idols' (Je. 50:38, // pěsîlîm).

Burns concludes appropriately:

The above survey of word and text discloses a surprising assortment of terms for images. The context, with few exceptions one of condemnation, indicates by its very nature that the use of these images was persistent and, to those loyal to YHWH-only, profoundly troubling. Images were commissioned and owned by households and monarchs alike. They were erected in household shrines and temples. Such images were made of stone, of wood carved or forming a core covered with precious metals, cast of silver or gold or a cheap metal overlaid with the former ... Terracotta clay images are not directly mentioned ...86

Burns suggests nevertheless that figurines may be included in some of the general terms, notably 'élîlîm or tĕräpîm. However, neither of these is a close match. The former ('elillîm) is characteristic of Isaiah in the eighth century, so could fit chronologically. However some 'ělilîm could be made of metal, unlike JPFs. The latter (terrāpim) occurs in several narratives of times long before the JPFs were popular, but only sporadically in later prophetic condemnation.

None of these words seems to apply specifically to figurines. Some are associated with molten images, notably pesel, ělîl, ‘ăsabbîm and massēkāh. Some are too general, e.g. gillûlîm, šiqqûs and șelem. Some are too infrequent for the period when figurines flourished, e.g. těrāpîm and semel.

The figurines may have figured in general condemnation of images and idols. The prophets who lived when they flourished may have included them in their own preferred terms for idols, e.g. Isaiah in the 'elîlîm and Ezekiel in the gillûlîm. But they are not given their own specific term in the biblical text.

\section{Interpretation}

The textual data provides much evidence for worship of Asherah in the Levant, and the Hebrew Bible for worship of the goddess and a cultic 'asherah pole' before and during the Israelite monarchy. There is also much evidence of idols in Israel and Judah and their condemnation by the canonical writers. But there are no unambiguous references to figurines. So in synthesis we examine possible explanations of why

85 Maacah, named mother of both Abijam and Asa (1 Ki. 15:2,10), was likely grandmother of the latter.

86 Burns, 'Female', 29f. 
JPFs flourished in late monarchy Judah, and ask how this fits the biblical portrayal.

We have noted the remarkable uniformity in size and features of the JPFs, except for the two head types. Even here, hand-made and moulded heads conform closely within their groups. This strongly suggests a uniform identification and function. ${ }^{87}$ But what was their identity and function?

\subsection{Identity}

(1) Toys. Some scholars have proposed this for animal and bird figurines, or an unusual human figurine, e.g. a woman with a child at Tell Beit Mirsim. 88 And a few have proposed this for anthropoid figurines generally. ${ }^{89}$ However, this is unlikely. ${ }^{90}$ (a) JPFs are found in public buildings, an unlikely location for children's play. ${ }^{91}$ (b) They do not present the variety found elsewhere in toys. (c) The back of JPFs is crudely manufactured and left undecorated, so they were not intended for play. (d) They are not robust enough children. (e) There is no archaeological evidence to connect them with children. (f) There is no evidence of exposed parts being smoothed through usage.

(2) Human women, e.g. those seeking help in birth or in disease. This interpretation is also rare.92 Meyers notes the lack of divine attributes, and suggests they may represent humans and have sympathetic magic properties. ${ }^{93}$ But again, the great uniformity seems to imply a specific identity. Also it is hard to attribute to them a coherent function. As Kletter notes (74): 'an explanation of mortal women without symbolism doesn't fit what we know about ancient art'.

87 For Kletter, Judean, 79, proposing multiple meanings is 'a very easy way of escaping the problem'.

88 References in Kletter, Judean, 19, 73.

89 E.g. R de Vaux, Ancient Israel (London: DLT, 1961), 48f. Others listed in Kletter, Judean, 73; van der Toorn, 'Israelite', 52 n. 28.

90 So Kletter, Judean, 73, noting similar rejection of this view regarding other ANE figurines.

91 Van der Toorn, 'Israelite', 53, adds their presence in graves, but this would fit child burials.

92 P.R.S. Moorey notes 'strong comparative evidence from elsewhere that they may well be human suppliants', British Academy Review, July-December 2001, 28; also idem, Idols of the People: Miniature Images of Clay in the Ancient Near East (OUP, forthcoming).

93 C.L. Meyers, 'From Household to House of Yahweh: Women's Religious Culture in Ancient Israel', in A. Lemaire, ed., Congress Volume Basel 2001 (Leiden: Brill, 2002), 286; idem, Discovering Eve: Ancient Israelite Women in Context (New York: OUP, 1988), 162. Also tentatively H.J. Franken, M.L. Steiner, eds., Excavations in Jerusalem 1961-1967, Vol. II (Oxford: OUP, 1990), 128. 
(3) Mother goddess. Many scholars have proposed that the JPFs represent a generalised goddess figure, described variously as mother goddess, fertility goddess, naked goddess nursing/suckling goddess or Syrian goddess. ${ }^{94}$ However, the concept of a generalised unnamed goddess has been sharply criticised by others, for various reasons. (a) A major deity remaining unnamed does not fit what we know of the ancient world. (b) Every major known deity of the ancient Near East was 'mother' or 'father' to their followers, so 'mother goddess' is essentially tautologous. (c) Attributes of fertility or nurture are simply guesses which add nothing to the identification. (d) The description as 'naked' is at best only partially true of pillar figurines, and gives no identification. (e) The description as 'Syrian' is simply misleading. 95

(4) Astarte or Anat-Astarte-Asherah.96 Until discovery of the Ugaritic texts, the term 'Astarte figurines' was common. Though still occasionally used, sometimes simply for reference, ${ }^{97}$ it is now largely rejected given the evidence that Asherah was the main goddess of the Iron Age Levant. Some suggest that the goddess was named variously in different times and places, but remained essentially the same. Thus Dever (1994:122): "these are "Mother Goddess" figurines which represent the Great Lady in her various guises ... At Ugarit and elsewhere in the Late Bronze Age the Lady was known principally as Asherah, but sometimes she also appears as Anath, Astarte, Elath or Qadshu, "the Holy One". By Israelite times, however, her various personae and names had coalesced to Asherah ...'98 However, while the properties of major goddesses may have been similar, these goddesses are not normally confused in ancient texts. Anat was a Canaanite deity of the second millennium; Astarte was associated with the Phoenicians and northern Israel; and Asherah was venerated at various locations in the Levant, at least from LBA Ugarit onwards. There is no evidence that Anat and Astarte were acknowledged in late monarchy Judah, so they are hardly appropriate titles for the JPFs.

(5) Asherah. This is now by far the most common explanation. The biblical texts show that Asherah was the main female deity venerated

\footnotetext{
94 Kletter, Judean, 74, lists some twenty scholars.

95 The term goes back at least to 1949 (cf. Holland, 'Study', 121 n. 1).

96 NB Astarte (initial ayin) and Asherah (initial aleph) are more distinct than appears in English.

97 E.g. Holland, 'Study', 124, 154; Stern, 'Religion', 250; Hadley, Cult, 188.

98 W.G. Dever, 'Ancient Israelite Religion: Differing Textual and Artifactual Portraits', in W. Dietrich, M.A. Klopfenstein, eds, Ein Gott allein? (Freiburg: Universitätsverlag, 1994), 122. Critiqued by Kletter, Judean, 22, and S.A. Wiggins, 'The Myth of Asherah: Lion Lady and Serpent Goddess', UF 23 (1991) 383.
} 
during the monarchy, however much reforming kings and canonical writers may have opposed her cult. The latter even admit that Asherah was occasionally promoted in the official state cult, notably by Maacah in the tenth century and Manasseh in the seventh. Many scholars conclude that Asherah was a regular part of the official cult throughout the monarchy, and Josiah's exclusive Yahwism, perhaps presaged by Hezekiah's, was innovative rather than reforming.

Also, many now argue that there were widespread regional or unofficial cults at various places (e.g. bāmôt), and family cult practices. These differed in tone and content from the Jerusalem cult, and included various practices like ancestor veneration (těrāpîm?), commemorative feasts (like the Akkadian kispum), and worship of Asherah. The JPFs are simply another aspect of this. 99

But if JPFs represent Asherah, why did they flourish particularly in late monarchy Judah? Neither biblical nor extrabiblical data provide much help. The kingdom of Judah initially enjoyed relative independence and affluence, followed by Assyrian domination and Babylonian subjugation. But nothing clearly links the JPFs to these political changes. The biblical text implies that worship of Asherah, or at least her cultic symbol, was a constant temptation. But this existed long before the eighth century. One might surmise that, following Maacah's promotion of Asherah worship, the ninth-century reforming kings Asa, Jehoshaphat and Joash maintained worship of Yahweh without a consort, 100 but this lacks direct textual and archaeological support. There is no discernable reason why Asherah figurines should begin to flourish in eighth-century Judah.

JPFs have been found in public buildings, homes and tombs. This would fit their identification with a deity whose blessing was invoked in public, in private and in death. Nevertheless, Kletter adds a caution: 'There is no clear evidence for cult in relation to the JPFs, but neither is the exact form of veneration of the Biblical Asherah clear.' 101

JPFs have also been found in domestic waste, so were not themselves regarded as specially holy and needing special disposal. Perhaps they were replaced from time to time, e.g. after a fall, and could then be disposed of along with ordinary household waste.

The flared base has sometimes been taken to represent a tree trunk, thus linking the JPFs to Asherah's cultic symbol. However, Kletter

99 Kletter, Judean, 78, warns against using figurines to prove house cults and house cults then to identify figurines.

100 Also, all the eighth-century Judaean kings except Ahaz reportedly 'did what was right in the eyes of Yahweh', though only Hezekiah initiated reform.

101 Kletter, Judean, 76. 
shows convincingly that this argument is 'baseless':102 both wood for statues and pillar bodies for figurines were widespread throughout the ancient Near East, and pillar bodies were also used in Judah for birds and horseback riders. The flared base fulfils the more prosaic purpose of enabling the figurine to stand upright.

\subsection{Function}

(1) Magical use. This view was common in the early twentieth century, when magic and religion were often opposed. Some thought that pillar figurines were associated with 'bad magic' and were deliberately broken or mutilated. ${ }^{103}$ However, as shown above, there is no clear evidence of such breakage or mutilation. Later, from the mid-twentieth century onwards, they were described as lucky charms. 104 This fits their form better, since the moulded heads at least have an open smiling face. But this still does not fully explain them. Why exactly would such a figurine bring good luck?

(2) Votive offerings. These were common elsewhere in the ancient Near East, with images of human body parts, deities and their animal emblems offered to the deity in petition or thanksgiving. Israelite shrines may have received such tokens of hope and gratitude, e.g. Goliath's sword at Nob. 105 However, the JPFs were located primarily in houses, not shrines. As van der Toorn concludes, 'there is not one example of a figurine demonstrably donated as a votive gift'. ${ }^{106}$

(3) Veneration or devotion. This is now the most common explanation of the JPFs: the figurines expressed a popular devotion to Asherah. Thus most homes had one, but only needed one; some public buildings had them, as did some tombs. As substitutes for a cultic image, they could be produced simply and cheaply, and replaced when broken or buried.

\subsection{Other Factors}

JPFs are often found along with other more numerous figurines, particularly quadrupeds (often indistinguishable) and birds. These are similar to the JPFs in manufacture (though without moulded heads), decoration, and distribution. However, the animals and birds are

\footnotetext{
102 Kletter, Judean, 77, without noting the pun!

103 E.g. Holland, 'Study', 137.

104 Kletter, Judean, 77, cites literature from 1938 to 1990.

105 So van der Toorn, 'Israelite', 58.

106 Idem, 59. J.M. Sasson, 'A Response to Karel van der Toorn', in Gittlen, ed., Sacred, 65, adds that 'when inscribed, Mesopotamian votive figurines tended to represent the worshipers as readily as the deities'.
} 
seldom identified with deities. ${ }^{107}$ Perhaps they were arrayed around the goddess to indicate her beneficence.

There are also a few horse-and-rider figurines, often with horses and riders found separately. Since this was a common ancient imagery for a male deity, many suggested that the rider represents Yahweh. There is a virtually complete absence of male figurines on their own during this period.

A trend towards aniconism in late monarchy Judah is increasingly posited. Sass, Uehlinger and others analyse data regarding seals, 108 and note that the general near eastern trend towards aniconism by the seventh century was appreciably stronger in Judah. This trend predated the Josianic reform, and may have been partly due to increasing literacy, reducing the need for identification by picture. But arguably it was also influenced by the reform: 'It is a definitely plausible hypothesis, then ..., to suspect that this new fervour for God's name might have been influenced by the growing insistence of Judean seal-cutters and their customers on what could aptly be termed "name-alone" seals.' 109 Similarly, Mettinger argues cogently for a general trend towards a programmatic aniconism in late monarchy Judah. ${ }^{110}$ Further, if the female figurines represent Asherah, the paucity of male figurines is likely evidence of aniconism regarding Yahweh.

\subsection{Conclusions}

(1) The JPFs testify to the importance of a female figure in popular religion in the late monarchy period. (2) They may well represent Asherah, the main goddess of this area and time. However, the significance of possessing such an Asherah figurine remains unclear. (3) They were treated as objects of some importance, as shown by their decoration. However, they were not sacred objects, since they were discarded when damaged. (4) Biblical writers did not see JPFs as any more a threat to Yahwism than other images or unapproved cultic places and activity. There was no specific term for JPFs, and they were not singled out for specific condemnation. If they represented Asherah they were indicative of Judaean apostasy rather than a key element of

\footnotetext{
107 Franken and Steiner, Excavations, 128, identify bird figurines with Asherah.

108 B. Sass, C. Uehlinger, eds, Studies in the Iconography of Northwest Semitic Inscribed Seals (Göttingen: Vandenhoeck \& Ruprecht, 1993) However, A.R. Millard, Review of N. Avigad, B. Sass, Corpus of Ancient West Semitic Stamp Seals, in IEJ 51 (2001), 83, notes that such aniconic seals were common both earlier and elsewhere.

109 Uehlinger in Sass and Uehlinger, Studies, 288.

110 T.N.D. Mettinger, No Graven Image (Stockholm: Almqvist and Wiksel, 1995), and various articles.
} 
it. (5) If they indicate such apostasy, the widespread ownership of JPFs supports prophetic and deuteronomistic indictment of the nation. In particular, it lends credence to the bleak conclusion of Jeremiah (3:11) and Ezekiel (23:11) that Judah had become worse than Israel. Theologically, they show Yahweh's punishment of his people was fully justified. (6) The virtual absence of post-exilic Judaean figurines shows the positive effect of the exile. For all the traumatic upheaval and theological reappraisal it occasioned, the exile clearly had the effect of removing images and figurines from Judaean religion. In this respect at least, Yahweh's people had received a new heart. 